\title{
Uji Toksisitas Subkronik 28 Hari Kombinasi Ekstrak Metanolik Benalu Teh dan Benalu Mangga Terhadap Profil Protein pada Tikus Wistar (Rattus norvegicus) Betina
}

\author{
Umu Intan Kinasih ${ }^{1 *)}$, Nour Athiroh $\mathrm{AS}^{2 * *)}$, Nurul Jadid $\mathrm{M}^{3)}$
}

${ }^{1), 2), 3)}$ Departement of Biology FMIPA UNISMA, Indonesia

\begin{abstract}
ABSTRAK
Profil protein adalah parameter yang seringkali digunakan sebagai indikator untuk mendeteksi adanya kerusakan pada fungsi hepar. Munculnya kerusakan pada fungsi hepar akan memberikan informasi tentang pemaparan suatu zat terhadap tubuh makhluk hidup. Tujuan penelitian ini adalah untuk mengetahui efek toksik dari kombinasi ekstrak benalu teh dan benalu mangga terhadap profil protein dalam darah dengan pemaparan secara terusmenerus (subkronik) selama 28 hari. Analisis data menggunakan uji ANOVA one-way software SPSS versi 17.0. Hewan uji yang digunakan dalam penelitian ini adalah tikus wistar betina sebanyak 20 ekor dengan empat perlakuan yaitu kontrol, perlakuan 1 dengan dosis $250 \mathrm{mg} / \mathrm{KgBB}$, perlakuan 2 dengan dosis $500 \mathrm{mg} / \mathrm{KgBB}$ dan perlakuan 3 dengan dosis $1000 \mathrm{mg} / \mathrm{KgBB}$. Hasil dari penelitian ini menunjukkan tidak berbeda nyata rerata kadar total protein dan albumin antara kontrol dan kelompok perlakuan. Ditinjau dari hasil rerata kadar globulin menunjukkan perbedaan yang nyata antara perlakuan dengan kontrol. Tiga parameter yang diteliti dua diantaranya menunjukkan hasil tidak beda nyata antara tikus kontrol dengan tikus yang dipapar dengan EMBTBM (tikus yang diberi perlakuan). Kesimpulan menunjukkan bahwa pemaparan EMBTBM aman terhadap profil protein dan tidak menyebabkan efek toksik pada tikus Wistar betina dikarenakan nilai rerata kadar profil protein yang meliputi total protein, albumin dan globulin dalam keadaan stabil dan tidak mengalami peningkatan berlebih.
\end{abstract}

Kata kunci: Subkronik, Total Protein, Albumin, Globulin, Toksisitas.

\begin{abstract}
There are 3 indicators for indicating a protein breakdown in the blood through a total protein, albumin, and globulin stability. A compound capable of acting as antioxidants is needed to stabilize the protein's condition. This research is aimed at identifying the toxic effects of extract's combination from tea parasite and mango parasite on the conditions of blood's protein by giving EMBTBM constantly for 28 days. The data analysis used ANOVA one-way by SPSS version 17.0. As for the animal test used was a female Wistar rat of 20 with four treatments are control, treatment 1 with a dose of $250 \mathrm{mg} / \mathrm{Kg}$ body weight $(\mathrm{BW})$. Treatment 2 with a dose of $500 \mathrm{mg} / \mathrm{Kg}$ body weight $(B W)$ and treatment 3 with a dose of $1000 \mathrm{mg} / \mathrm{Kg}$ body weight $(B W)$. The result of this research shows that there is no difference between treatment and control over the results of a total protein and albumin. But, at the result of globulin, there is a difference between treatment and control. Therefore, EMBTBM is safe for profile protein and does not cause toxicity because protein is stable and not over-reducing.
\end{abstract}

Keywords:Subchronic,Total Proteins, Albumine, Globuline, Toxicity

*) Umu Intan Kinasih, Biologi FMIPA Universitas Islam Malang, J1. MT. Haryono 193, Malang Tlp 081332802375 e-mail intan.kinasih96@gmail.com

**) Dr. Nour athiroh A.S., S.Si, M.Kes, Biologi FMIPA Universitas Islam Malang, Jl. MT. Haryono 193, Malang Tlp 081330017206 e-mail nur_athiroh_mlg@yahoo.co.id

doi: $10.33474 /$ e-jbst.v7i1.354

Diterima tanggal 16 Agustus 2020- Diterbitkan Tanggal 31 Agustus 2021

http://creativecommons.org/licenses/by/4.0 


\section{Pendahuluan}

Umumnya tanaman benalu dikenal sangat merugikan bagi masyarakat. Namun, sebuah penelitian membuktikan bahwa persepsi yang telah berkembang adalah kesimpulan yang kurang benar. Benalu teh dan benalu mangga adalah salah satu tanaman parasit. Benalu teh adalah tanaman yang mengandung sebanyak 16 senyawa bioaktif. Hasil uji skrining fitokimia menunjukkan bahwa benalu teh memiliki beberapa senyawa metabolit sekunder berupa alkaloid, flavonoid, tanin, quersetin, saponin, inulin, dan glikosida yang berpotensi sebagai antioksidan [5]. Benalu mangga juga merupakan tanaman parasit yang dapat dijumpai pada tanaman mangga (Mangifera indica). Benalu mangga juga memiliki kandungan senyawa metabolit sekunder berupa fenolik, tanin, asam amino, karbohidrat, alkaloid, dan saponin. Kandungan senyawa fenolik pada benalu mangga mempunyai aktivitas farmakologi sebagai antioksidan [8].

Menurut BPOM (2014) uji toksisitas merupakan salah satu uji yang bertujuan untuk mendeteksi efek toksik suatu zat pada sistem biologi. Penelitian uji toksisitas dari benalu teh pada mencit yang telah dilakukan sebelumnya menunjukkan hasil tidak berbeda nyata, yang artinya pemaparan benalu teh tidak menyebabkan efek toksik [4]. Kerusakan pada hepar adalah parameter bioklinis yang diteliti karena hepar merupakan salah satu organ yang sering dijadikan sebagai sasaran dari zat toksik yang masuk ke dalam tubuh. Selain itu hepar juga merupakan salah satu organ yang menjadi tempat terjadinya sintesis protein [7].

Penelitian ini dilakukan bertujuan untuk mendeteksi adanya efek toksik akibat pemaparan kombinasi ekstrak metanolik benalu teh dan benalu mangga terhadap profil protein dengan parameter total protein, albumin, dan globulin pada tikus wistar betina secara subkronik selama 28 hari.

\section{Material dan Metode}

\section{Bahan dan Alat}

Bahan yang digunakan dalam penelitian ini adalah benalu teh, benalu mangga, methanol $90 \%$, aquades, tikus wistar betina 20 ekor dengan umur 6-8 minggu dan BB 100-200g, pakan tikus, sekam, obat bius ketamine, larutan BPS (phosphate buffered saline), dan formalin $10 \%$.

Alat yang digunakan adalah timbangan analitik, oven, botol, toples kaca, blender, gelas beaker, cawan petri, rotary evaporator, lemari pendingin, handscoon beserta masker, kandang tikus beserta tutup, botol air minum tikus, galon $5 \mathrm{~L}$, alat sonde, toples plastik, spuit injeksi $2 \mathrm{~mL}$, alat bedah, parafin blok, tabung vacutainer, dan plastik sampah.

\section{Metode}

Penelitin ini adalah penelitian yang menggunakan True Experimental Design dengan rancangan acak lengkap (RAL). EMBTBM dipaparkan pada hewan uji secara subkronik (terus-menerus) selama 28 hari. Hewan uji yang digunakan adalah tikus galur wistar betina sebanyak 20 ekor, yang dibagi dalam empat kelompok; kelompok pertama adalah kelompok kontrol. Kelompok kedua, ketiga, dan keempat adalah kelompok tikus yang diberikan perlakuan dosis EMBTBM. Dilakukan pula penimbangan berat badan tikus setiap minggu untuk menentukan dosis yang akan diberikan pada minggu selanjutnya. Tahapan penelitian yang terakhir adalah pembedahan seluruh tikus. Tikus dibedah guna dilakukan pemeriksaan pada serum darah terkait profil protein, kemudian dilakukan perbandingan antara tikus kontrol dengan tikus yang berikan perlakuan EMBTBM secara subkronik selama 28 hari.

Analisis data yang digunakan adalah analisis ragam satu arah atau dengan Analysis of Variance (ANOVA). Analisis ini menggunakan aplikasi SPSS versi 17.0 dengan sistem operasi windows. Analisis statistik terhadap rerata akan dianggap berpengaruh atau menunjukkan beda nyata bila tingkat kepercayaan atau $(\mathrm{P}<0,05),{ }^{\mathrm{a}}$. 


\section{Cara Kerja}

\section{Ekstraksi Maserasi}

Benalu teh dan benalu mangga yang telah diidentifikasi di balai Materia Medika Batu disortir daunnya, kemudian daun benalu teh dan benalu mangga dikeringkan dengan menggunakan oven dengan suhu $40-60^{\circ} \mathrm{C}$ hingga kandungan air pada daunnya hilang. Daun benalu teh dan benalu mangga yang telah kering kemudian diblender hingga menjadi simplisia bubuk [6]. Simplisia bubuk daun benalu teh dan benalu mangga ditimbang sebanyak 100g, kemudian dimasukkan ke dalam botol berukuran 1,5L . Simplisia bubuk benalu teh dan benalu mangga kemudian direndam dengan methanol $90 \%$ dan dishake selama 60 menit agar simplisia dengan methanol 90\% menjadi homogen. Setelah dishake, kemudian rendaman simplisia didiamkan selama $1 \times 24$ jam. Supernatan hasil dari perendaman simplisia kemudian dievaporasi (diuapkan) dengan menggunakan evaporator dan diberikan label untuk membedakan ekstrak yang telah berbentuk pasta. Ekstrak yang dihasilkan harus disimpan dalam lemari pendingin. EMBTBM disondekan pada tikus selama 28 hari secara subkronik dengan ketentuan dosis yang bertingkat yaitu $250 \mathrm{mg} / \mathrm{KgBB} ; 500 \mathrm{mg} / \mathrm{KgBB}$; dan $1000 \mathrm{mg} / \mathrm{KgBB}$. Pada hari ke-29 tikus wistar dibedah dan diambil serumnya untuk mengetahui kadar total protein, albumin dan globulin.

\section{Pengukuran Total Protein}

Sebanyak $20 \mu \mathrm{L}$ serum uji direaksikan dengan $1000 \mu \mathrm{L}$ pereaksi uji untuk pemeriksaan total protein dalam tabung reaksi $5 \mathrm{~mL}$ dan dihomogenkan dengan bantuan votex. Absorbansi diukur dengan mengguanakan spektrofotometer pada suhu $37^{\circ} \mathrm{C}$ selama 5 menit. Pada panjang gelombang $540 \mathrm{~nm}$. Hal yang sama juga dilakukan terhadap blangko (pereaksi+aquades) dan standar (pereaksi+standar total protein). Kadar total protein dapat dihitung dengan membandingkan absorbansi sampel dengan absorbansi protein standar yang dikalikan dengan konsentrasi kadar protein standar [2].

\section{Pengukuran Albumin}

Sebanyak $10 \mu \mathrm{L}$ serum uji direaksikan dengan $1000 \mu \mathrm{L}$ pereaksi uji untuk pemeriksaan kadar albumin dalam tabung reaksi $5 \mathrm{~mL}$ dan dihomogenkan dengan bantuan vortex. Absorbansi diukur dengan menggunakan spektrofotometer pada suhu $37 \mathrm{C}$ selama 5 menit. Pada panjang gelombang $546 \mathrm{~nm}$. Hal yang sama juga dilakukan terhadap blangko (pereaksi+aquades) dan standar (pereaksi+standar albumin). Kadar albumin dapat dihitung dengan membandingkan absorbansi sampel dengan absorbansi albumin standar yang dikalikan dengan konsentrasi kadar albumin standar [2].

\section{Pengukuran Globulin}

Sebanyak $10 \mu \mathrm{L}$ serum uji direaksikan dengan $1000 \mu \mathrm{L}$ pereaksi uji untuk pemeriksaan kadar globulin dalam tabung reaksi $5 \mathrm{~mL}$ dan dihomogenkan dengan bantuan vortex. Absorbansi diukur dengan menggunakan spektrofotometer pada suhu 37C selama 5 menit. Pada panjang gelombang $546 \mathrm{~nm}$. Hal yang sama juga dilakukan terhadap blangko (pereaksi+aquades) dan standar (pereaksi+standar globulin). Kadar globulin dapat dihitung dengan membandingkan absorbansi sampel dengan absorbansi globulin standar yang dikalikan dengan konsentrasi kadar globulin standar [2].

\section{Ethical Clearance}

Penelitian ini telah mendapatkan persetujuan dari Komisi Etik Penelitian FK UB (Ethical Clearance) nomor: 369/EC/KEPK/06/2015. 
e-Jurnal Ilmiah BIOSAINTROPIS (BIOSCIENCE-TROPIC)

Volume : 7 / No : 1 / Halaman 9 - 15 / Agustus Tahun 2021

ISSN : 2460-9455 (e) - 2338-2805(p)

\section{Hasil dan Diskusi}

\section{Hasil Penelitian}

\section{Pengujian Kadar Total Protein, Albumin dan Globulin}

Berdasarkan analisis ANOVA, EMBTBM yang dipaparkan selama 28 hari secara subkronik antara tikus perlakuan dosis $250 \mathrm{mg} / \mathrm{KgBB} ; 500 \mathrm{mg} / \mathrm{KgBB} ; 1000 \mathrm{mg} / \mathrm{KgBB}$ tidak berbeda nyata dengan tikus kontrol $(\mathrm{P}>0,05)$ dapat dilihat pada gambar 1.

Hasil rerata kadar albumin antara kelompok tikus dengan perlakuan dengan tikus kontrol juga menunjukkan hasil analisis yang tidak berbeda nyata $(\mathrm{P}>0,05)$ dapat dilihat pada gambar 2 , sedangkan rerata kadar globulin terjadi perbedaan antara kelompok tikus perlakuan dengan tikus kontrol setelah dipapar dengan EMBTBM selama 28 hari secara subkronik dapat dilihat pada gambar 3.

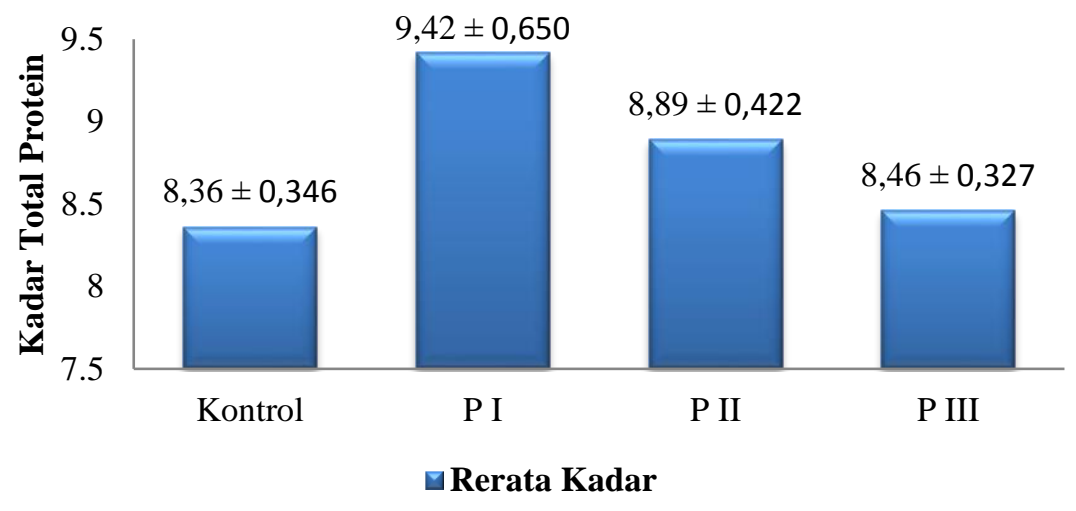

Gambar 1. Histrogram Rerata Total Protein (g/dL) pada Serum Tikus Wistar Setelah Pemaparan EMBTBM Selama 28 Hari

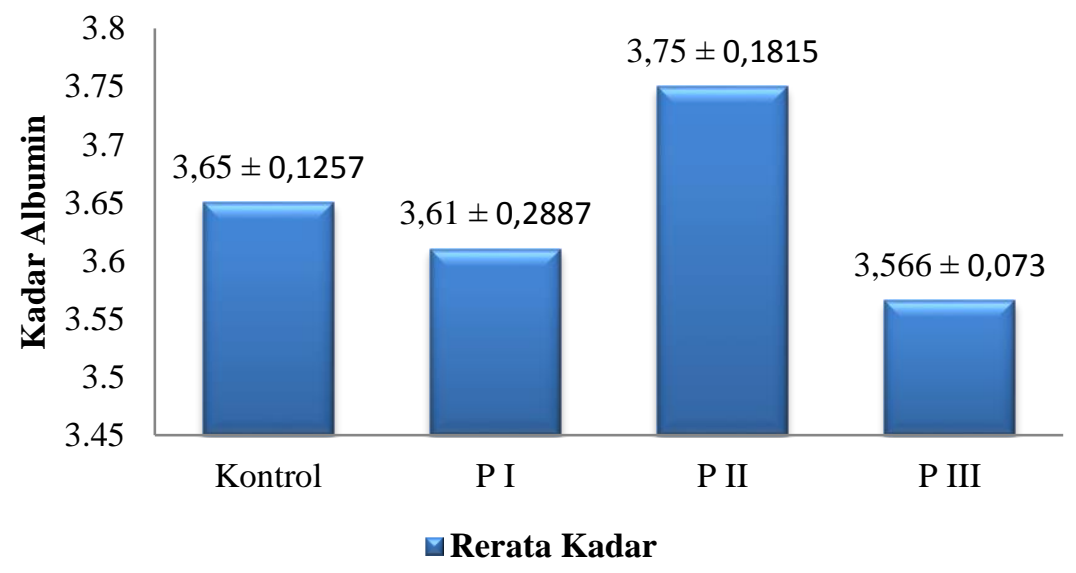

Gambar 2. Histogram Rerata Kadar Albumin (g/dL) pada Serum Tikus Wistar Setelah EMBTBM Selama 28 Hari 




\section{Gambar 3. Histogram Rerata Kadar Globulin (g/dL) pada Serum Tikus Wistar Setelah EMBTBM Selama 28 Hari.}

\section{Pembahasan}

Dalam serum darah terdapat beberapa komponen protein yang dapat digunakan sebagai indikator untuk menunjukkan keadaan organ lain. Profil protein adalah salah satu komponen yang dapat menggambarkan keadaan dan fungsi hepar. Profil protein dalam darah dapat digambarkan oleh tiga parameter yaitu total protein, albumin dan globulin. Keadaan dan fungsi hepar dapat diketahui dengan mengamati kadar total protein, albumin dan globulin yang merupakan jenis protein plasma yang disintesis di hepar. Kerusakan hepar dapat diketahui dengan mengukur jumlah poliribosom (RE) sintesa protein. Total protein, albumin dan sebagian globulin disinteis pada poliribosom yang terikat membran, dengan demikian protein plasma melintasi jalur sekretorik utama pada sel yaitu mulai dari membram retikulum endoplasma kasar menuju ke membran retikulum endoplasma halus kemudian memasuki aparatus golgi dan akhirnya disimpan dan dibawa vesikel sekretorik masuk ke dalam plasma [3,4].

Hasil kadar total protein (gambar 1) menunjukkan bahwa pemaparan EMBTBM yang dilakukan selama 28 hari secara subkronik pada Rattus norvegicus dengan dosis paling tinggi yaitu $1000 \mathrm{mg} / \mathrm{KgBB}$ tidak menyebabkan efek toksik terhadap hepar, hal tersebut dapat ditunjukkan pada nilai rerata kadar total protein dari kelompok tikus perlakuan masih dalam batas normal. Nilai pada kontrol $(8,36 \mathrm{~g} / \mathrm{dL})$ dan kelompok perlakuan PI (9,42 g/dL), PII (8,89 g/dL), dan PIII (8,46 g/dL). Hasil rerata kadar albumin (gambar 2) juga menunjukkan hal sama, yaitu nilai-nilai rerata yang muncul masih dalam batas normal, dengan nilai rerata kadar albumin pada kontrol $(3,56 \mathrm{~g} / \mathrm{dL})$ dan kelompok perlakuan PI $(3,614 \mathrm{~g} / \mathrm{dL})$, PII $(3,75 \mathrm{~g} / \mathrm{dL})$, dan PIII $(3,566 \mathrm{~g} / \mathrm{dL})$. Hal yang sama juga terjadi pada rerata kadar globulin dengan nilai tikus kontrol (4,712 g/dL) dan kelompok tikus perlakuan PI (5,802 g/dL), PII (5,478 g/dL), dan PIII (4,5 g/dL) juga masih dalam batas normal.

Jika diamati antara kontrol dengan kelompok perlakuan tidak mempunyai nilai rerata kadar yang terpaut jauh. Hasil kadar rerata total protein dan kadar globulin sempat mengalami kenaikan nilai kadar rerata pada dosis $250 \mathrm{mg} / \mathrm{KgBB}$, namun pada dosis selanjutnya yaitu dosis $500 \mathrm{mg} / \mathrm{KgBB}$ mengalami penurunan dan menurun lagi pada dosis $1000 \mathrm{mg} / \mathrm{KgBB}$. Hal tersebut berbeda dengan rerata kadar albumin yang mengalami penurunan pada dosis awal yaitu $250 \mathrm{mg} / \mathrm{KgBB}$ dan mengalami peningkatan pada dosis $500 \mathrm{mg} / \mathrm{KgBB}$ dan menurun kembali pada dosis $1000 \mathrm{mg} / \mathrm{KgBB}$. Peningkatan dan penuruan yang terjadi pada kadar albumin dapat dihubungkan pada [2], apabila telah terjadi penurunan nilai pada suatu parameter uji di pemberian dosis awal maka tidak perlu memberikan dosis yang lebih tinggi. Namun jika dilihat pada satu titik dosis yaitu pada dosis $1000 \mathrm{mg} / \mathrm{KgBB}$ maka dapat 
diketahui bahwa hasil penelitian tersebut sesuai dengan kurva dosis. Dosis obat berbanding lurus dengan respon obat, apabila semakin tinggi dosis yang diberikan maka semakin kuat efek terapi yang ditimbulkan [4]. Pernyataan sebelumnya telah menjelaskan bahwa pada dosis $1000 \mathrm{mg} / \mathrm{KgBB}$ menekan peningkatan yang terjadi pada dosis $250 \mathrm{mg} / \mathrm{KgBB}$ atau dosis $500 \mathrm{mg} / \mathrm{KgBB}$, sehingga pada perlakuan dengan pemparan dosis $1000 \mathrm{mg} / \mathrm{KgBB}$ menunjukkan nilai rerata kadar yang setara dengan tikus kontrol baik pada total protein, albumin dan globulin. Menurut [1], peningkatan dan penurunan yag terjadi pada fraksi-fraksi protein plasma adalah suatu hal yang harus diperhatikan, dikarenakan peningkatan atau penurunan kadar total protein, albumin dan globulin yang terjadi secara signifikan juga menjadi salah satu tanda bahwa sedang terjadi kerusakan pada fungsi hepar.

Berdasarkan hasil skrining fitokimia menunjukkan bahwa tanaman benalu teh dan benalu mangga memiliki beberapa kandungan metabolit sekunder yang mempunyai aktivitas farmakologi berupa antioksidan. Kandungan metabolit sekunder yang terdeteksi pada benalu teh yaitu; tanin, flavonoid, kuersetin, glikosida, alkaloid, saponin dan inulin. Kuersetin merupakan salah satu kandungan utama flavonoid. Kuersetin merupakan suatu aglikon yang apabila berikatan dengan glikonnya maka akan membentuk suatu ikatan glikosida [4,5,7], sedangkan pada benalu mangga flavonoid, tanin, asam amino, karbohidrat, alkaloid, dan saponin. Kandungan utama pada benalu teh adalah flavonoid dalam bentuk kuersetin [8]. Kuersetin adalah salah satu jenis flavonoid yang mempunyai aktivitas farmakologi berupa antioksidan. Antioksidan bekerja untuk menstabilkan radikal bebas yang terdapat di dalam tubuh. Antioksidan menangkap radikal bebas (gugus hidroksil) pada kerusakan hepatosit yang terdapat pada kerusakan hepar. Gugus hidroksil senyawa falvonoid memberikan atom hidrogen kepada radikal bebas sehingga radikal bebas menjadi stabil dan proses kerusakan haptosi pada hepar mampu terhenti. Benalu teh dan benalu mangga diujikan dalam penelitian ini adalah EMBTBM yang berbentuk pasta. Pelarut yang digunakan dalam proses ekstraksi adalah methanol. Methanol adalah pelarut yang mudah menguap sehingga pada proses evaporasi pelarut methanol akan benar-benar hilang dari ekstrak, sehingga pasta yang diujikan pada tikus wistar hanya mengandung zat-zat biokatif yang telah diikat methanol sebelumnya.

\section{Kesimpulan}

Berdasarkan analisis data menggunakan uji ANOVA pada penelitian ini dapat disimpulkan bahwa nilai rerata kadar total protein, albumin, dan globulin antara tikus kontrol dengan kelompok tikus perlakuan menunjukkan tidak berbeda nyata, sehingga dapat disimpulkan bahwa pemaparan EMBTBM pada Rattus norvegicus selama 28 hari secara subkronik aman bagi pofil protein pada serum tikus wistar dan tidak memberikan efek toksik terhadap profil protein serum tikus wistar (Rattus norvegicus).

\section{Ucapan Terima Kasih}

Penulis mengucapkan terimakasih kepada Direktorat Jenderal Pendidikan Tinggi, Kementerian Riset dan Teknologi Pendidikan Tinggi, yang telah memberikan hibah kepada team untuk dapat mengembangkan penelitian ini dengan nomor; 112/G164/U.LPPM/K/B.07/IV/2019. Perihal pemberitahuan penerimaan proposal penelitian tahun 2019 untuk pendanaan tahun 2020-2022 tertanggal 18 Juli 2019. Penelitian Terapan Unggulan Perguruan Tinggi (PTUPT) dengan judul “ Kombinasi Herbal Benalu sebagai Sediaan Produl Firofarmaka Suatu Kandidat Alternatif Obat Anti Hipertensi Alami Tradisional Indonesia" yang diketuai oleh Dr. Nour Athiroh AS,. S.Si, M.Kes. 
e-Jurnal Ilmiah BIOSAINTROPIS (BIOSCIENCE-TROPIC)

Volume : 7 / No : 1 / Halaman 9 - 15 / Agustus Tahun 2021

ISSN : 2460-9455 (e) - 2338-2805(p)

\section{Daftar Pustaka}

[1] Kaslow, J. E. 2010. Analysis of Serum Protein. Santa Ana: 720 North Tustin Avenue Suite 104, CA.

[2] BPOM, badan pengawas Obat dan Makanan. 2014. Uji Toksisitas Non Klinik In Vivo. Pedoman No. 875.

[3] Athiroh, N and N. Permatasari. 2012. Mechanism of Tea Mistletoe Action on Blood Vessels Medical. Journal Brawijaya.Vol. 27 No.(1) Page: 1-7.

[4] Athiroh, N., Sammad, F. H. A., dan Santoso, H. 2017. Pemberian Ekstrak Metanolik Scurulla atropurpurea (Bl) Dans Secara Subkronik Terhadap Total protein Dan Albumin Tikus Betina. Jurnal BIOSAINTROPIS. Vol. 2 (2); 49-54.

[5] Athiroh, N dan D, Wahyuningsih. 2017. Study of Superoxide Dismutase and Malondialdehyde Concentrations in Mice After Administration of Methanolic Extract of Scurrula atropurpurea (BL.). Jurnal Kedokteran Hewan. Vol.11(1); 19-22.

[6] Athiroh, N., Sulistyowati E. 2015. Evalution of Methanolic Extract of Scurrula atropurpurea (BI.) Dans Sub-Chronic Exposure on Wistar Rat Liver. AENSI Journal. ISSN-19950756.

[7]Athiroh, N., N. Permatasari, D. Sargowo dan M.A. Widodo. 2014. Effect of Scurrula atropurpurea on Nitric Oxide, Endothelial Damage, and Endothelial Progenitor Cells of DOCA- salt Hypertensive rats. Iranian Journal of Basic Medical Sciences. Vol. 17 No.8, page: 622-625.

[8] Sasongko, P dan Mushollaeni, W. 2017. Efek Paparan Alginat dalam Pangan Terhadap Kadar Total protein, Albumin dan Globulin Darah. Buana Sains Vol. 17(2): 189-196.

[9] Sembiring, B. H., Sovia, L dan Lamek, M. 2016. Aktivitas Antioksidan Senyawa Flavonoida dari Daun Benalu Kakao (Dendrophthoe pentandra (L.)Miq). Chimica et Natura Acta. Vol. 4(3): 117-122.

[10] Healthoracle. 2014. Globulin. http://healthoracle.org/download/G/Globulin.pdf. Diakses pada 7 juni 2020. 